\title{
Investigation of the Moderator Role of University Conditions Under the Effect of Personality Traits on Entrepreneurship Competence*
}

\author{
Kişilik Özelliklerinin Girişimcilik Yetkinliği Üzerinde Etkisi Sürecinde \\ Üniversite Koşullarının Moderatör Rolünün İrdelenmesi*
}

\author{
Deniz KOYUNCUOGLU, Mahmut TEKiN
}

\begin{abstract}
This study aimed to investigate the moderator effect of university conditions in the relationship between personality traits and entrepreneurial competence. In this cross-sectional study, the questionnaire method used in quantitative studies was preferred to obtain primary data. The population of the research is the students of Selçuk University in Konya and consists of 3rd and 4th year students studying in 2018-2019 academic year. Personal information form, Entrepreneurial-Innovative University Conditions Scale, Scale of Entrepreneurial Competencies and The Five-Factor Personality Inventory were used as data collection tools. Multiple linear regression analysis was used to analyze the data. The results show that personality traits have a positive effect on entrepreneurial competence. It was found that university conditions did not have a moderator effect in the relationship between personality traits and entrepreneurial competence. Some suggestions were offered considering the results obtained.
\end{abstract}

Keywords: Entrepreneurial competence, Higher education, Moderator variable, Personality traits, University conditions

\section{ÖZ}

Bu çalışmada, kişilik özelliklerinin girişimcilik yetkinliği üzerinde etkisi sürecinde girişimci-yenilikçi üniversite koşullarının moderatör rolünün irdelenmesi amaçlanmıştır. Bu amaçla anket yöntemiyle elde edilen veriler SPSS 24.0 paket programıyla analiz edilmiş ve üniversite öğrencilerinin kişilik özellikleri, girişimci-yenilikçi üniversite koşullarına ilişkin algıları ve girişimcilik öz-yetkinlikleri arasındaki ilişkilerin demografik, aile, çalışma/iş durumu ve teknoloji faktörleri açısından nedensel ve ilişkisel tarama modelleri ile incelenmiştir. Bu bağlamda Türkiye'nin büyük üniversitelerin birinde saha araştırması yapılmış öğrencilere anket uygulanmıştır. Elde edilen sonuçlara göre, üniversite koşullarının kişilik özellikleri ile girişimcilik yetkinliği arasında moderatör etkisi bulunmamaktadır. Bununla birlikte araştırma sonuçlarına göre öğrencilerin girişimci-yenilikçi üniversite koşullarına ilişkin algılarının ve kişilik özelliklerinin girişimcilik yetkinliklerini anlamlı düzeyde yordadığı görülmüştür. Öğrencilerin girişimcilik yetkinlikleri en güçlü şekilde yordayan değişkenin kişilik özellikleri olduğu görülmüş̧ür. Ayrıca araştırmada öğrencilerin girişimcilik yetkinliklerin demografik, fakülte, bölüm, sınıf, aile, çalışma/iş durumu, teknolojiye ilgi duyma ve teknoloji alanında proje yapma faktörleri açısından anlamlı farklılıklar göstermektedir.

Anahtar Sözcükler: Girişimcilik yetkinliği, Yükseköğretim, Moderatör değişken, Kişilik özellikleri, Üniversite koşulları

Koyuncuoglu D., \& Tekin M. (2021). Investigation of the moderator role of university conditions under the effect of personality traits on entrepreneurship competence. Journal of Higher Education and Science/Yükseköğretim ve Bilim Dergisi, 11(1), 138-149. https://doi.org/10.5961/jhes.2021.436

\footnotetext{
* This study is derived from the PhD dissertation "Investigating the Moderator Role of University Conditions in the Process of Impact of Personality Traits on Entrepreneurship Competence" under the supervision of Professor Dr. Mahmut TEKiN in Institute of Social Sciences, Department of Business Administration at Selcuk University.

*Bu çalışma Selçuk Üniversitesi Sosyal Bilimler Enstitüsü Iş̧letme Anabilim Dalı Prof.Dr.Mahmut TEKiN danışmanlığında "Kişilik Özelliklerinin Girişimcilik Yeterliliğine Etkisi Sürecinde Üniversite Koşullarının Moderatör Rolünün Incelenmesi" adlı doktora tezinden alınmış̧ır.
}

Deniz KOYUNCUOGLU (四)

ORCID ID: 0000-0002-4068-8386

Kırklareli University, Kırklareli, Turkey

Kırklareli Üniversitesi, Kırklareli, Türkiye

deniz.bas@klu.edu.tr

Mahmut TEKiN

ORCID ID: 0000-0003-0558-4271

Selçuk University, Department of Business Administration, Konya, Turkey

Selçuk Üniversitesi, İşletme Bölümü, Konya, Türkiye

Received/Geliş Tarihi : 10.03 .2020

Accepted/Kabul Tarihi : 18.04.2021 


\section{INTRODUCTION}

Universities directing science and technology have been continuing their education, training and research activities in the changing world for centuries. Today, the change in the perspective of social dynamics and public policies prompts universities to make their position and function in society more effective. In fact, universities take on an entrepreneurial identity in order to use the information they obtain as a result of their education and research activities more actively (Barbak, Burmaoğlu, \& Esen, 2016). In this study, this study aimed to determine how universities' entrepreneurial identities affect the relationship between students' personality traits and entrepreneurial competencies. Thus, it will be better understood how university conditions affect students' entrepreneurial personality traits and entrepreneurial competencies.

\section{Entrepreneurial Competence}

The concept of competence is at the heart of strategy and human resource management. Conceptually, competence is defined as a combination of resources and skills from the perspective of strategic management (Cardy \& Selvarajan, 2006). Competencies have a key role in the advantages that will provide competitive advantage for businesses. Even if the strategies are well positioned, it is not possible to realize them successfully without the necessary competencies. While competence is defined as the combination of personal characteristics such as knowledge, skill, and motivation (Özutku \& Algur, 2012), it is defined as more than the sum of knowledge and skill and the characteristic or quality associated with the person's effective performance (Turan, 2015).

The decision to start concrete planning activities for entrepreneurship, start a business or take over a business or develop and grow a business depends on a number of factors that affect each other. In this process, realization of entrepreneurship intent for planning or concrete entrepreneurial action requires entrepreneurship competence (Kailer \& Weiß, 2018). Entrepreneurial competence, attitude, belief, talent, personality, skill and behavioral tendencies are necessary entrepreneurial features to sustain business success (Kiggundu, 2002). Dynamism, flexibility and self-regulation skill are critical for entrepreneurship to remain an entrepreneur (Markowska, 2011). Entrepreneurial competence requires entrepreneurial knowledge and entrepreneurial motivation. Entrepreneurship consists of knowledge and experience. Entrepreneurial motivation is the sum of attitudes and intentions (Kailer, 2005; Kailer \& Weiß, 2018).

\section{Entrepreneurial University}

As with all other institutions created by the society, universities are in constant interaction with the society and change with the society over time. As universities begin to raise the standard of living with the important role they have for the satisfaction of interest groups, they present various strategies for the solution of the problems of the society (Top \& Öner, 2008). As universities have a universal structure, they have been affected by social and structural changes throughout the history. Wissema (2014) divides the change of universities into three types; (1) education-oriented medieval universities based on classical science and theology-based philosophy, (2) education-teaching and research-oriented Humboldtian universities and (3) entrepreneurial and innovative universities that promote entrepreneurship as well as education, training and research.

It is seen in the literature that the concept of entrepreneurialinnovative university is interpreted in many different forms and dimensions. While evaluating the concept of entrepreneurial university, Odabaşı (2007) states that entrepreneurial university practices include a wide range of practices or aims from merely raising student wages, being a university that works closely with the business world, the success of academics in finding funds, the ability to transfer information to customers in the public or private sector through education and research to applications covering a holistic transformation process. However, a narrow point of view and the difference of interpretation towards commercial concerns may be disruptive to universities and this does not constitute an example for corporate university entrepreneurship. Today, in addition to the concept of "Entrepreneurial University", it is seen that the concepts of "Creative University", "Service University", "Learning University" and "Proactive University" are also used. No matter what concept or nomenclature is used, the "Entrepreneurial University" model, or "Entrepreneurial Innovative University" model, which may be valid in practice for today's universities, has gained importance (Odabaşı, 2007).

While the entrepreneurial-innovative university phenomenon was coined to the theoretical ground by Etzkowitz (1983) as the university that conducts contract research to find new funding sources and can enter commercial relations with private companies; it was described as the university that has founded or pioneered the establishment of new companies with academics, students and experts by Chrisman, Hynes, \& Fraser (1995); as the university that carries out all the legal activities to ensure the commercialization of the researches carried out within the university in order to make technology transfer and commercial enterprises by Dill (2003); as the university in close cooperation with the industry and the business world who take responsibility for their stakeholders to create new outsourcing, and use managerial tools such as leadership and planning corporate management by Subotzky (1999); as the university researching how to make the business world more innovative and creative, by Clark (1998) and as the university based on both commercialization and commodification by Jacob, Lundqvist, and Hellsmark (2003).

Robertson (2008: 1) outlines the key features of the entrepreneurial-innovative university as follows:

- Strong leadership that enhances entrepreneurial capacities for all students and employees,

- Establishing strong ties with external stakeholders that provide added value, 
- Providing entrepreneurial-innovative outputs that affect individuals and organizations,

- Innovative learning techniques that excite and activate for entrepreneurial action,

- Establishing clear boundaries to ensure effective information flow between organizations,

- Multidisciplinary approaches focusing on solving complex world challenges in education and reflecting the real world experience,

- Feeling the urge to encourage entrepreneurial-innovative thinking and leadership practices.

\section{Personality Traits}

As in the past, many studies have been carried out to understand and classify people today. In the studies carried out up to now, the concept of "personality", which comes from the word "persona" in Latin, has been defined as the person's distinctive characteristics, the person's distinctive condition, in other words, a combination of the person's "unique" features. In the Turkish Language Association Dictionary (TDK), the word "personality" means a distinctive feature specific to a person; the totality of the moral and spiritual qualities; character. While defining the concept of personality as personally identifiable and permanent features, researchers have also stated that the concept of personality also consists of a combination of genetically derived character and subsequently acquired character (Akiskal, Hirschfeld, \& Yerevanian, 1983; Mc Adams, 1997, Norman, 1963). There are different measuring tools to measure personality traits in the literature. The measurement tool based on the five-factor personality model is one of the most used measurement tools. This tool measures personality with dimensions of extraversion, conscientiousness, openness to experience, agreeableness and neuroticism (John \& Srivastava, 1999).

\section{Personality Traits and Entrepreneurship}

Determining the successful entrepreneurial personality depends on both the entrepreneurial competency characteristics of the person and the question of the suitability of the person for entrepreneurship, in other words personality traits (Rathgens, 2012). One of the important factors that affect entrepreneurial characteristics is the personality traits that are innate and acquired later. Numerous studies have shown that psychological variables and other personal factors affect both entrepreneurial trends and entrepreneurial actions (Müller, 2003; Minniti, Bygrave, \& Autio, 2006; Raab \& Neuner, 2008). Although there is an agreement on the importance of the subject, there is no consensus on the definition and related characteristics of entrepreneurial personality. This situation can be explained on the one hand by the interdisciplinary science of entrepreneurship and on the other hand by the structure inherent in the personality (Braukmann, Bijedic, \& Schade, 2008).

The research of entrepreneurial personality traits has been considered as an important subject in the science of entrepreneurship for many years and its roots are based on the studies of Schumpeter (1934). Scientific research of the subject started in the 1960s. The empirical determination of entrepreneurial personality traits is based on the work of McClelland (1965). In McClelland's work, he identified 5 characteristics that distinguish the entrepreneur from the non-entrepreneur. These are need of achievement, risk-taking propensity, locus of control, tolerance for ambiguity and need for autonomy. McClelland's model of determining personality traits has been applied to students as part of competitions organized to increase students' need for success in the USA. Subsequent studies have shown that McClelland's model of determining personality traits is associated with not only entrepreneurs, but also everyone with high success. For this reason, it is stated that McClelland's entrepreneurial personality concept is not an appropriate instrument in distinguishing the characteristics of entrepreneurs and non-entrepreneurs (Saßmannshausen, 2008). Although McClelland's approach has been methodically criticized by researchers, it has a pioneering character in scientific discussions in determining entrepreneurial personality traits.

Some studies have shown that five-factor personality traits are related to entrepreneurship, including conscientiousness/ self-control, extraversion/introversion, agreeableness/ compatibility/reconciliation/amiability/vulnerability, neuroticism, and openness to experience (Goldberg, 1992). The process of starting a business usually takes place in an uncertain environment. Therefore, this stage is characterized by stress and uncertainty. Bureaucratic procedures, formal processes and relationship networks, in other words, contact with support organizations, customers, partners, suppliers and others are important activities (Korunka, Kessler, Frank \& Lueger, 2011). A healthy circumvention of this stage is related to the neurotic personality trait. Low level of neuroticism will benefit the entrepreneur (Caliendo \& Kritikos, 2014). The entrepreneur's ability to think conceptually at this stage will have an impact on the success of the business initiative. This skill is especially necessary when creating a business plan. They need to persuade potential funders. In addition, while dealing with many factors in the realization of the business idea, they should also plan the next stage and know what to do. This will help the entrepreneur to take decisions regarding the risk taking level, the factors of self-control and need for control, and the step to be taken for entrepreneurship. Then, it will not be possible to return to the preparatory phase without losses (Schick, 2007). Sales take place in the middle of the establishment and the stabilization phase. However, these sales do not generate enough turnover. In the stabilization phase, entrepreneurs should have the ability to persuade. This stage is characterized by the launch of the product. The entrepreneur should use his creative skills to create the marketing model. Thus, creativity coincides with openness to experience. Since not every enterprise runs flawlessly, the entrepreneur may face situations such as frustration and daunting that cause disappointment. Uncertainties, such as the inability to collect debts from the customer, should be taken into account. Once the revenues from the sales cover the costs, the entrepreneur 
will have reached the breakeven point. The entrepreneur starts to grow after this point. As a result, the entrepreneur is at the center of the entrepreneurial process. The process starts with the business idea of the entrepreneur and realizes the business idea thanks to his management role as a manager (Pott \& Pott, 2012). Therefore, it can be argued that there is a tight connection between the entrepreneurship process and the entrepreneur's personality trait.

\section{Purpose of the Research}

When the literature is reviewed, we see that there is a close relationship between university students' personality traits, education and incentives and entrepreneurial competencies (Muofhe \& Toit, 2011; Patrr \& Karahan, 2010; Setiawan, 2014; Thomson \& Minhas, 2017). No research has been found that addresses the university as an entrepreneurial ecosystem considering all the activities of the university as a whole and investigates what effects students have towards the end of the four-year undergraduate program. From this point of view, it can be suggested that there is a need for a field research that will bring an integrated approach.

It is possible to come across conceptual and empirical studies in the literature that personality traits affect entrepreneurial competence (Brandstätter, 1997; Schmitt-Rodermund, 2004; Rauch \& Frese, 2007; Çetin \& Varoğlu, 2009; Vatansever, 2011). However, it has not been investigated how the opportunities provided by universities leading the training of entrepreneurial individuals affect the relationship between personality traits and entrepreneurial competence. This research will help to better understand the impact of internal environmental conditions, education, awareness, incentive and support activities and personality traits on entrepreneurial competence at universities. The theoretical models and hypotheses developed in accordance with the purpose of the research are as follows.

H1: Personality traits have a positive effect on entrepreneurial competence.

H2: University conditions have a moderator effect on the effect of personality traits on entrepreneurial competence.

\section{Method}

In this cross-sectional study, the survey method used in

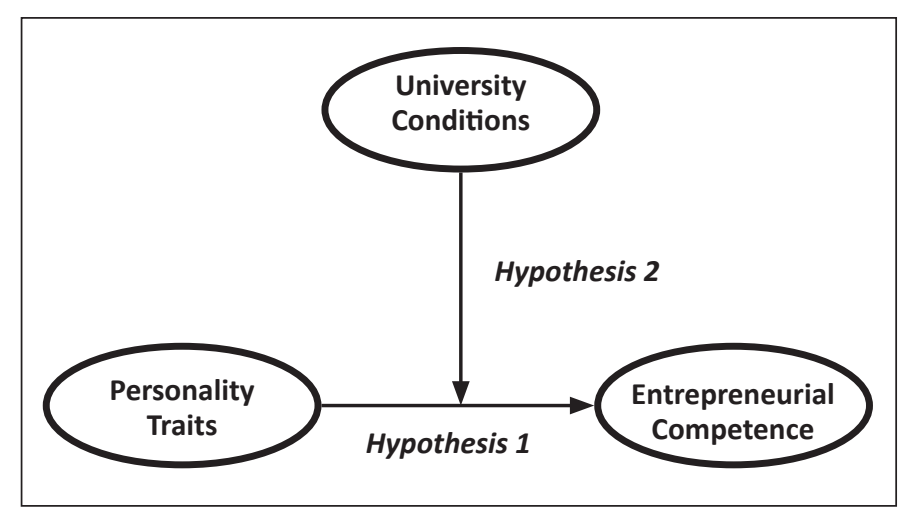

Figure 1: Research model. quantitative research was preferred to obtain primary data. The reason and purpose of this method is to measure the perceptions of the subjects about university conditions, entrepreneurial competencies and personality traits without taking too much of their time. Data were obtained by using questionnaire. Questionnaire is defined as a research material that consists of a series of questions to describe people's living conditions, behaviors, beliefs or attitudes. It is a method of data collection, which consists of reading a questionnaire consisting of a large number of questions by or to the subjects and recording the answers (Yıldırım, 2015).

\section{Population Sample}

The population of the research is the students of Selçuk University in Konya and consists of 3rd and 4th year students studying in 2018-2019 academic year. In this research, the higher educational institution that is aimed to be evaluated from the perspective of students is Selçuk University. The fact that Selçuk University has been among the top 50 universities in the Entrepreneurial and Innovative University Index every year since 2012 is effective in determining the research population.

The students who are targeted to be evaluated in the research are students who study in the departments of the Faculty of Economics and Administrative Sciences (departments of Business Administration, Economics, Public Administration, International Relations, International Trade), departments of the Faculty of Engineering (Mechanical, Civil, Industrial, Computer, Electrical Electronics, Chemical, Geomatic, Environmental, Geological, Mining, Metallurgy and Materials Engineering) and Natural Sciences of Konya Technical University. The reason for the application of the research in the Faculty of Economics and Administrative Sciences and the Faculty of Engineering is that the students who graduated from these faculties were engaged in entrepreneurship activities (McNally, Martin, Honig, Bergmann, \& Piperopoulos, 2013).

The population consists of 7.444 students in the research. The number of students randomly selected to represent 7,444 students in the $95 \%$ confidence interval $(\alpha=0.05)$ is 370 (Yazıcıoğlu \& Erdoğan, 2014). More students were included in the research considering that there may be absentees during data collection. A total of 900 students were given questionnaires and the sample size was exceeded. Cluster sampling technique, one of the probable sampling methods, was used in accordance with the purpose of the research. According to Khanal (2016), in the cluster sampling, the sample units include element groups-sets (schools, faculties, departments, etc.). The researcher has the flexibility to increase the sample size using this technique. This sampling technique is preferred because it shows distribution in clusters in terms of the variables investigated in the target population (university students). The distribution of students in the sample of the study according to demographic characteristics is shown in Table 1.

It is seen from the Table 1 that the majority of the students participating in the study are in the age group 21-25 years $(60 \%)$. When the gender status of the students is analyzed, it is 
Table 1. Distribution of Students Included in the Research According to Demographic Features

\begin{tabular}{|c|c|c|c|}
\hline & & $\mathbf{n}$ & $\%$ \\
\hline \multirow{3}{*}{ Age } & $18-21$ years old & 325 & 36.1 \\
\hline & $21-25$ years old & 540 & 60.0 \\
\hline & 26 years old and older & 35 & 3.9 \\
\hline \multirow{2}{*}{ Gender } & Female & 444 & 49.3 \\
\hline & Male & 456 & 50.7 \\
\hline \multirow[t]{2}{*}{ Faculty } & Economics and Administrative Sciences & 343 & 38.1 \\
\hline & Engineering and Natural Sciences & 557 & 61.9 \\
\hline \multirow{2}{*}{ Class } & 3rd grade & 489 & 54.3 \\
\hline & 4 th grade & 411 & 45.7 \\
\hline \multirow{4}{*}{ Family monthly income } & Minimum wage & 118 & 13.1 \\
\hline & $2.021-5.000 \mathrm{tl}$ & 521 & 57.9 \\
\hline & $5.001-7.500 \mathrm{tl}$ & 172 & 19.1 \\
\hline & $7.501 \mathrm{tl}$ and above & 89 & 9.9 \\
\hline \multirow{2}{*}{ Interest in technology } & No & 72 & 8.0 \\
\hline & Yes & 828 & 92.0 \\
\hline
\end{tabular}

seen that $49.3 \%$ are female and $50.7 \%$ are male. $38.1 \%$ of the students study in the Faculty of Economics and Administrative Sciences, $61.9 \%$ of them are in the Faculty of Engineering and Natural Sciences. While $13.1 \%$ of the families of the participants have minimum wage income, $57.9 \%$ have a monthly income of 2.021-5.000 TL, $19.1 \%$ of 5.001-7.500 TL and 9.9\% of them have a monthly income of 7.501 TL and above. A large percentage of students stated that they were interested in technology (92\%).

\section{Data Collection}

The measurement tool form consisting of personal information form, university conditions scale, entrepreneurial competencies and personality traits scales used in the study was applied by the researcher using the personal interview method. The questionnaire was not sent by mail due to the limited working time and being in the same environment with students. During the face-to-face applications conducted by the researcher, university students were given detailed information about the study and it was stated that the participation was on a voluntary basis. The duration of the questionnaires is about 15 minutes.

\section{Measuring Tools}

\section{Entrepreneurial-Innovative University Conditions Scale}

The Entrepreneurial-Innovative University Conditions Scale developed by Tekin, Koyuncuoğlu, Geçkil, \& Baş (2019) was used to measure university students' perception of entrepreneurialinnovative university. The scale consisting of 30 items has a three-subscale structure. Subscales are determined as awareness and education, incentive and support, and the university environment. The scale is a 5-point Likert type and the scale items are rated from 1 (Strongly disagree) to 5 (Strongly agree). High scores from the scale indicate that the perception of entrepreneurial-innovative university is high.
The factor structure of the measuring tool was re-examined. Before factor analysis, it was checked whether the items that make up the Entrepreneurial-Innovator Scale disrupt the scale structure. As a result of the analysis, the total correlation value of the 11 items in the scale was found lower than 0.5 and the related items were removed from the scale. After the item analysis, the measuring tool included 19 items.

To test the structural validity of the measuring tool, the scale items were subjected to varimax rotation principal component analysis. As a result of factor analysis, it was found that the scale has a three-dimensional structure. The eigenvalue of each dimension is greater than 1 . The dimensions explain $77.73 \%$ of the total variance and the factor load of all items is greater than 0.5 . It was also found that the items in the factors were compatible with the original form of the scale.

The reliability level of the Entrepreneurial-Innovative University Conditions Scale was calculated by calculating the Cronbach alpha coefficient. The alpha coefficient should be 0.70 and higher in order for the reliability of the measurement tools to be sufficient (Tavşancıl, 2005). The Cronbach alpha coefficients calculated for the university environment, awareness and education, incentive and support factors of the scale were found as $0.95,0.95$ and 0.94 , respectively. These values showed that the reliability of the scale based on internal consistency was high.

\section{Entrepreneurial Competencies Scale}

"Entrepreneurial Competencies Scale" developed by Tekin, Baş, Geçkil, \& Baş (2019) was used to determine the university students' perception of entrepreneurial competencies. The scale consisting of 25 items has a two-subscale structure. Subscales are stated as background knowledge and motivation. The scale is a 5-point Likert type and the scale items are 
rated from 1 (Strongly disagree) to 5 (Strongly agree). High scores obtained from the scale indicate that perception of entrepreneurial competence is high.

In this study, the factor structure of the measuring tool was re-examined. Whether the items that make up the Entrepreneurship Competencies scale disrupt the structure of the scale was checked before factor analysis. As a result of the examinations, the total correlation value of the 10 items in the scale was found to be less than 0.5 and the related items were removed from the scale. After the item analysis, 15 items remained in the measuring tool.

The scale items were subjected to varimax rotation principal component analysis to test the structural validity of the measuring tool. It was found that the scale has a twodimensional structure. The eigenvalue of each dimension is greater than 1 . The dimensions explain $75.53 \%$ of the total variance and the factor load of all items is greater than 0.50 . Thus, the items in the factors were compatible with the original form of the scale.

The Cronbach Alpha coefficient was calculated and the reliability level of the Entrepreneurial Competencies Scale was examined. The alpha coefficient must be 0.70 and higher for the reliability of the measuring tools to be sufficient. The alpha coefficients 1 and close to 1 indicate high reliability due to internal consistency (Tavşancıl, 2005). It is understood that the scale's Cronbach alpha coefficients calculated for entrepreneurship motivation and entrepreneurship accumulation factors are 0.94 and 0.95 , respectively. These values indicated that the reliability of the measurement tool due to internal consistency was high.

\section{Five-Factor Personality Inventory}

Five-Factor Personality Inventory developed by John and Srivastava (1999) and adapted to Turkish by Kocabacak (2011) was used to determine the personality traits of university students. The scale has five dimensions: extraversion, conscientiousness, openness to experience, agreeability and neuroticism. The scale, which is a five-point Likert type, consists of 44 items. Scale items range from 1 (Strongly disagree) to 5 (Strongly agree). High scores from any personality dimension indicate that the personality is dominant in the individual. In this study, the factor structure of the five-factor personality inventory was re-examined. Before factor analysis, it was checked whether the items that make up the inventory disrupt the structure of the scale. The analysis revealed that the total correlation value of 28 items in the scale was less than 0.5 and the related items were removed from the scale. After item analysis, 16 items remained in the measuring tool.

To test the structural validity of the measuring tool, the scale items were subjected to varimax rotation principal component analysis. As a result of the factor analysis, it was found that the inventory has a four-dimensional structure (Extraversion, Agreeableness, Conscientiousness and Openness to Experience). The eigenvalue of each dimension is greater than 1 . The dimensions explain $82.14 \%$ of the total variance and the factor load of all items is greater than 0.50 . Therefore, the items in the factors were compatible with the original form of the scale.

Cronbach Alpha coefficient was calculated and the reliability level of the personality inventory was analyzed. In order for the reliability of the measurement tools to be sufficient, the alpha coefficient must be 0.70 and higher. The alpha coefficients 1 and close to 1 indicate high reliability due to internal consistency (Tavşancıl, 2005). It is seen that the Cronbach alpha coefficients calculated for the extraversion, agreeableness, conscientiousness and openness to experience factors are $0.90,0.95,0.93$ and 0.88 , respectively. These values showed that the scale's reliability based on internal consistency was sufficient.

\section{Statistical Analysis of Data}

Some assumptions have been checked before applying the necessary analyzes to test the hypotheses developed in the research. In the first step, the distribution of the scores obtained from the measurement tools is examined. Box plots were created to detect extreme values that prevent the distribution from approaching normal. When the graphs are examined, it is found that there are no extreme values or values that prevent normal distribution. In the next stage, the skewness and kurtosis coefficients of the mean scores obtained from the entrepreneur-innovative university conditions, entrepreneurship competencies and personality traits measurement tools were calculated. The skewness and kurtosis coefficients in the range of \pm 1 indicate that the mean scores have a normal distribution (Tabacnick \& Fidell, 2007). The calculated coefficients pointed out that the scores obtained from the measurement tools met the normal distribution assumption (Table 2).

The relationship between Entrepreneurial-Innovative university conditions, entrepreneurship competencies and scores obtained from personality traits measurement tools was examined by applying Pearson Correlation analysis. Correlation analysis was applied to determine the strength and direction of the relationship between the two variables evaluated. In the correlation analysis, the coefficients between 0 and \pm 0.30 denote low correlation, the coefficients between \pm 0.31 and \pm 0.70 display moderate, and the coefficients between \pm 0.71 and \pm 1 show high correlation (Büyüköztürk, 2006).

Regression analysis was applied to determine the effect of personality traits on entrepreneurial competence and to determine the moderator effect of university conditions in the relationship between personality traits and entrepreneurial competence. Before the analyses were performed, assumptions have been made that must be met for multivariate analyzes. To do this, first, multivariate extreme value analysis was performed by calculating Cook distance values. The calculated distance values below 1 indicate that multivariate extreme values are not in the data set (Field, 2009). The highest Cook distance value calculated in the study was 0.03 . The results showed that multivariable extreme values were absent in the dataset. 
Then, the assumption of the independence of errors was examined, for this the Durbin-Watson coefficient was calculated. The fact that this coefficient was in the range $(>1.5$ and $<2.5$ ) indicates that the assumption of independence of errors was met (Kalaycl, 2017). The Durbin-Watson coefficients calculated in this study were between 2.04 and 2.06. This value showed that the relevant assumption was met. In the last step, VIF (variance inflation factor) values were calculated to investigate the multicollinearity problem. VIF values of 10 and above indicate that there is multicollinearity between independent variables (Çokluk, Şekercioğlu, \& Büyüköztürk, 2012). The calculated values $(\mathrm{VIF}=1.00)$ indicated that there was no multicollinearity between the independent variables in the analysis. As a result, it was found that the data were suitable for multivariate analysis. Data were analyzed using SPSS 24.0.

\section{FINDINGS}

Before testing the hypotheses developed for the purpose of the study, the relationships between the variables were examined by calculating the Spearman Brown correlation coefficients (Table 3). In the next step, regression analysis was applied to test the developed hypotheses. In the last step, the scores obtained from the data collection tools were analyzed by comparing them according to the demographic variables in the table below.

As seen in the correlation matrix in Table 3 , it is seen that there was a positive, moderate and statistically significant correlation between personality traits and entrepreneurial competence $(r=0.422 ; p<0.05)$. It is seen that there was a positive, low level and statistically significant correlation between university conditions and entrepreneurial competence $(r=0.194 ; p<0.05)$. There was a low level of positive and insignificant correlation between personality traits and university conditions $(r=0.115$; $p>0.05)$.

To test the first hypothesis of the research, the effect of personality traits on entrepreneurial competence was examined by regression analysis. Personality traits and independent entrepreneurial competence were dependent variables in regression analysis. The results are shown in Table 4.

It is seen that the Entrepreneurial competence $=\mathrm{b} 0+\mathrm{b} 1$ and personality traits model proposed in Table 4 are statistically significant $(F=207.576$ and $p<0.001)$. According to the results of the regression analysis, $\mathrm{R}^{2}$ (percent of the explained

Table 2: Skewness and Kurtosis Coefficients of Scores Obtained from Measurement Tools

\begin{tabular}{l|c|c|c|c|c|}
\hline \multirow{2}{*}{ Variables } & \multirow{2}{*}{$\mathbf{n}$} & \multicolumn{2}{|c|}{ Skewness } & \multicolumn{3}{c|}{ Kurtosis } \\
\cline { 3 - 6 } & & Value & SH & Value & SH \\
\hline Entrepreneurial Knowledge & 900 & -0.35 & 0.08 & 0.50 & 0.16 \\
Entrepreneurial Motivation & 900 & -0.20 & 0.08 & -0.27 & 0.16 \\
\hline University Environment Conditions & 900 & -0.13 & 0.08 & -0.13 & 0.16 \\
\hline Awareness and Training Activities & 900 & 0.07 & 0.08 & 0.15 & 0.16 \\
\hline Incentive and Support Activities & 900 & -0.29 & 0.08 & 0.13 & 0.16 \\
\hline Extraversion & 900 & -0.11 & 0.08 & -0.09 & 0.16 \\
\hline Agreeableness & 900 & -0.10 & 0.08 & -0.10 & 0.16 \\
\hline Conscientiousness & 900 & -0.18 & 0.08 & -0.20 & 0.16 \\
\hline Openness to experience & 900 & -0.21 & 0.08 & 0.24 & 0.16 \\
\hline
\end{tabular}

Table 3: Pearson Correlation Coefficients for Relationships between Entrepreneurial-Innovative University Conditions, Entrepreneurial Competencies and Scores Obtained from Personality Traits Measurement Tools

\begin{tabular}{c|c|c|c|c|c|c} 
& Variables & $\overline{\mathbf{X}}$ & $\mathbf{S d}$ & $\mathbf{1 .}$ & $\mathbf{2 .}$ & $\mathbf{3 .}$ \\
\hline 1. & Personality traits & 3.25 & 0.98 & 1 & & \\
\hline 2. & Entrepreneurial competence & 3.21 & 0.84 & $0.422^{*}$ & 1 & \\
\hline 3. & University conditions & 2.85 & 0.79 & 0.115 & $0.194^{*}$ & 1 \\
\hline
\end{tabular}

Note: ${ }^{*} p<0,05$

Table 4: Regression Analysis Results to Determine the Effect of Personality Traits on Entrepreneurial Competence

\begin{tabular}{|c|c|c|c|c|c|c|}
\hline The dependent variable & $\mathbf{R}^{2}$ & Independent variables & $\beta$ & Std. Error & $\mathbf{t}$ & $\mathbf{F}$ \\
\hline Entronronourial comnotonco & 187 & Fixed Term & 1.963 & 0.09 & $21.824^{*}$ & 20 \\
\hline 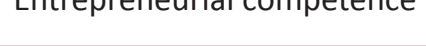 & $0.18 /$ & Personality characteristics & 0.383 & 0.027 & $14.408^{*}$ & $207.5 / 6$ \\
\hline
\end{tabular}

Note: ${ }^{*} p<0,001$. 
Table 5: Regression Analysis Results Regarding Moderator Effect

\begin{tabular}{|c|c|c|c|c|c|c|}
\hline Dependent variable & $\mathbf{R}^{\mathbf{2}}$ & Independent variables & $\boldsymbol{\beta}$ & Std. Error & $\mathbf{t}$ & $\mathbf{F}$ \\
\hline \multirow{4}{*}{ Entrepreneurial competence } & \multirow{4}{*}{0,207} & Fixed Term & 1.605 & 0.308 & $5.215^{*}$ & \multirow{4}{*}{$79.071^{*}$} \\
\hline & & Personality Traits (PT) & 0.355 & 0.092 & $3.881^{*}$ & \\
\hline & & University Conditions (UC) & 0.145 & 0.108 & $1.340^{* *}$ & \\
\hline & & Moderator Impact (PT x UC) & 0.004 & 0.032 & $0.127^{* * *}$ & \\
\hline
\end{tabular}

Note: ${ }^{*} p<0.001 ;{ }^{* *} p=0.181 ; * * * p=0.899$

variance) and $\mathrm{F}$ (degree of significance of the regression model) show that entrepreneurial competence can be explained by personality traits. Personality traits have a positive effect on entrepreneurial competence $(B=0.383 ; p<0.001)$. The first hypothesis was confimed based on these results.

To test the second hypothesis of the research, the effect of personality traits, university conditions and interaction variable (personality traits $x$ university conditions) on entrepreneurial competence was examined by regression analysis. The results are displayed in Table 5.

It is seen that the entrepreneurial competence $=b_{0}+b_{1}$, personality traits $+b_{2}$ and university conditions $+b_{3}$ (Personality Traits * University Conditions) model suggested in Table 5 are statistically significant $(F=79,071$ and $p<0.001)$. According to the results of the regression analysis, $\Delta R^{2}$ (percentage of the variance explained) and $F$ (degree of significance of the regression model) show that entrepreneurial competence can be explained by personality traits and university conditions and interaction variable (PT x UC). On the other hand, the effect of the interaction variable on entrepreneurial competence is not statistically significant $(B=0.004 ; t=0.127$ and $p=0.899)$. According to the results obtained, the second hypothesis was rejected. There is no moderator effect in the correlation between the personality traits of the university conditions and entrepreneurial competence.

\section{CONCLUSION, DISCUSSION and RECOMMENDATIONS}

An applied research was carried out on university students in the study. The aim of the research was to investigate the correlations between university students' personality traits, university conditions, and entrepreneurial competence perceptions. The results show that personality traits positively affect entrepreneurial competence. It was found that university conditions did not have a moderator effect on the correlations between personality traits and entrepreneurial competence.

Relationship between Personality Traits and Entrepreneurial Competence

Regression analysis conducted to determine the effect of personality traits and entrepreneurial-innovative university conditions on entrepreneurial competence revealed quite significant results in the research. Personality traits of university students significantly predict entrepreneurial competencies. Research findings show that approximately one-fifth of the changes in entrepreneurial competence stem from personality traits. The findings obtained in this study are similar to those of Murugesan and Jayavelu (2017) and Kerr, Kerr and Xu (2018). According to Kerr, Kerr and Xu (2018), the high impact of personality traits can be mentioned in entrepreneurial competencies, especially in the act of starting a new business venture. There is a strong relationship between the student's personality traits, existing entrepreneurial intentions, entrepreneurial talents, and personal enterprises. According to Murugesan and Jayavelu (2017), while extraversion from the Big Five personality traits has a positive effect on entrepreneurial intentions, neurotic trends negatively affect entrepreneurial competence by directing people to indecision in entrepreneurial intentions. In addition, the findings are similar to those of Singh and DeNoble's (2003) studies on students at a large state university on the west coast of the United States and that of Korunka, Frank, Lueger and Mugler (2003) on new entrepreneurial individuals in Austria.

Singh and DeNoble (2003) found strong correlation between students' five-factor personality traits and entrepreneurship in terms of talent and competence. According to the researchers, extraversion and openness to experience directly affect perceived talent and personal investment enterprise. According to Korunka et al. (2003), individuals who have just started a business should have strong entrepreneurial competencies, and perceptions about current trends and information. The metaanalysis study of Zhao, Seibert and Lumpkin (2010) revealed that consciousness, openness to experience, neuroticism and extraversion positively correlated with entrepreneurial business performance, which is measured by survival, growth and profitability of the businesses. According to the researchers, individuals with extraversion, agreeableness, and conscientiousness personality traits consider it important to develop their entrepreneurial competencies to achieve success in their new jobs using the learning individual characteristics. This makes them be successful in their jobs and improves their competencies.

In the study, it was found that university students' perception of entrepreneurial competence increased as they adopted extraversion, agreeableness, conscientiousness and openness to experience personality traits. These findings are similar to the results of the studies of Schumpeter et al. (2011), Rauch and Frese (2007), Zhao and Seibert (2006). We can talk about a multifaceted relationship between the personality traits of the potential entrepreneur, the difficulty level and motivation of the barriers encountered in starting a business. It was found 
that most students' perceptions of anxiety and obstacles in the field they will make attempts in the future affect their entrepreneurial motivation. However, the personality traits of the entrepreneur candidate are effective in dealing with these anxiety and obstacles (Sharma \& Madan, 2013). According to Schumpeter et al. (2011), the entrepreneur is an actor with the ability and motivation to carry out innovations described as new raw resources. The main motivation factor of the entrepreneur should be the realization of an idea. This is the creative stage of implementing ideas, where a certain degree of autonomy is important - perhaps a prerequisite - in the nature of basic motivation. Making profit, although not at the forefront as a motivational factor, is still an imperative to successfully implement an idea. Realization of ideas is not only mandatory for entrepreneurs but also a rare skill. Schumpeter stated that "ideas are cheap" and that everyone can have an idea, but only certain people have the capacity to realize an idea. According to the researchers, some personality traits are closely related to the motivation of the entrepreneurs described above. Therefore, both motivational structures and personality traits are important to understand the mentality of the entrepreneur.

According to Zhao and Seibert (2006), although the research on personality and entrepreneurship characteristics is comprehensive, it is a prerequisite to include motivation factors to fully capture the entrepreneurial mentality. According to Schumpeter, the main motives are the essence of the entrepreneurial mindset. According to Rauch and Frese (2007), some characteristics of individuals come to the fore in personality and entrepreneurial motivation. An extroverted interaction with social capital, being compatible with stakeholders, disciplined entrepreneurial activities, openness to innovation and experience reveals high motivational entrepreneurship and requires it in some cases.

\section{Moderator Effect of University Conditions}

The moderator effect of university conditions on the relationship between personality traits and entrepreneurial competence was investigated in this research. The results indicate that there is no moderator effect of the university conditions between the personality traits and entrepreneurial competence. This result is not consistent with the literature. According to the studies in the literature, entrepreneurial university conditions are directly related to entrepreneurial competence and personality traits. University conditions have a supportive effect on entrepreneurial personality traits and entrepreneurial competence (Morris, Shirokova, \& Tsukanova, 2017; Blenker, Dreisler, \& Kjeldsen., 2006; Koyuncuoğlu \& Tekin, 2019; Etzkowitz, 2004). It was emphasized in the research that creating an entrepreneurial university is closely related to the university's response to the changes in the environment, as well as the adaptation of the university to these changes. Regardless of their country, region or characteristics, universities are of great importance for the regions where they are located in supporting individual entrepreneurship, providing concrete resources and funding. The entrepreneurial character of the university, its relationship with stakeholders and its perception of the development of the environment (both internal and external) also contribute to the entrepreneur candidates creating an entrepreneurial image about their educational institutions. The good image provided by universities ensures that more students are active, more and more projects are developed and entrepreneurial activities are qualified (Etzkowitz, 2004). These explanations clearly show that universities and the opportunities they provide are related to individuals' entrepreneurial competencies.

The environmental conditions of individuals offer them some opportunities and/or constraints. Therefore, environmental conditions can affect one's attitude, behavior and personality. This indicates the importance of the organization, in other words, the environmental conditions on the individual's personality (Johns, 2006). Universities are also very important for students as an environment. A university student with an entrepreneurial personality can improve himself or herself in line with the opportunities provided by his or her university. Education and seminars, financial opportunities and internship opportunities organized by the university can stimulate the entrepreneurial potential of university students with their personality traits. Therefore, university conditions have an aspect that supports or disrupts students' entrepreneurial personality traits. Research supports these suggestions. It was found that university facilities and regional conditions are influential in the business activities, ideas and opinions of the students and graduates who set up business (Bergmann, Hundt, \& Sternberg, 2016). In some studies, it was stated that students gave up their business ideas and avoided new ventures as a result of the insufficient university conditions and the inability of universities to provide adequate training on entrepreneurship (Brown \& Kant 2008; Galloway \& Brown, 2002). It was emphasized that optimizing the environmental conditions within the university and creating a culture on entrepreneurship would positively affect the entrepreneurial personalities of students (Koyuncuoğlu \& Tekin, 2019). As a result, it is clearly seen that students' entrepreneurial personality traits are related to university conditions and are affected by them.

The findings obtained in this research are not in parallel with the theoretical explanations in the literature. One of the possible reasons for this situation may be that the individuals included in the research do not consider the opportunities provided by universities as important as they can affect their personality traits and entrepreneurial competence. One of the possible causes of this situation may be due to the fact that individuals participating in the research do not think that the opportunities provided by universities are important enough to affect their personality traits and entrepreneurial competencies. Perhaps the participants did not associate university facilities with their entrepreneurial competencies as they did not find the opportunities provided by their universities for entrepreneurship (environmental conditions, awareness and educational activities, incentive and support activities) sufficient or that these opportunities were not distributed fairly and transparently. Another possible reason for the 
finding may be that university facilities, educational activities and incentive areas were not arranged according to the needs and expectations of the students. As a matter of fact, some studies demonstrated that traditional education continues at universities, university conditions could not meet the needs and expectations of students, and entrepreneurship courses are offered only theoretically (Donckels, 1991; Fernie, Kantor, Klein, Meyer, \& Elgas, 1988; Koyuncuoğlu \& Tekin, 2019). It is of great importance that the university conditions are arranged effectively, and awareness and education activities are designed to provide the necessary skills for entrepreneurship. This will increase the self-confidence of students in the process of implementing an initiative. Thus, connections can be created between the vision that the students will gain and the actions related to the business idea they intend to carry out in the future (Johannisson, 1991).

This research also has some limitations. The research was carried out with students studying at one university. In order to increase the generalization of the results, the perceptions of university students about their personality traits, university conditions and entrepreneurial competence can be investigated on larger samples studying at different universities. In this research, the data were collected only through the questionnaire technique. In different studies, data can be obtained by using different data collection methods such as interview and observation methods. This research is based on cross-sectional design. In subsequent studies, long-term studies can be performed based on longitudinal design. Thus, the personality traits, university conditions and perceptions of entrepreneurship competence of university students can be better analyzed.

\section{REFERENCES}

Akiskal, H. S., Hirschfeld, M. A., \& Yerevanian, B. I. (1983). The relationship of personality to affective disorders. Arch Gen Psychiatry, 40, 801-810.

Barbak, A., Burmaoğlu, S., \& Esen, M. (2016). Araştırma üniversitesi olmak [Being a research university]. In: H. Yalçın, M. Esen, S. Burmaoğlu, \& M. F. Sorkun (Eds.), Bilim, teknoloji ve inovasyon çağında araştırma üniversitesi olmak [Being a Research University in the Age of Science, Technology and Innovation] (pp. 107-123). Ankara: Pegem Akademi.

Başol, O., Dursun, S., \& Aytaç, S. (2011). Kişiliğin girişimcilik niyeti üzerine etkisi: üniversiteli gençler üzerine bir uygulama [The effect of personality on entrepreneurial intention: an application on university students]. "işs Güç" Endüstri ilişkileri ve Insan Kaynakları Dergisi, 4(13), 7-22.

Bergmann, H., Hundt, C., \& Sternberg, R. (2016). What makes student entrepreneurs? On the relevance (and irrelevance) of the university and the regional context for student start-ups. Small Business Economics, 47(1), 53-76.

Blenker P., Dreisler P., \& Kjeldsen J. (2006). Entrepreneurship education - The new challenge facing the universities - A framework or understanding and development of entrepreneurial universitiy communities, working paper, Department of Management, Aarhus School of Business and University of Aarhus, Denmark.
Brandstätter, H. (1997). Becoming an entrepreneur - a question of personality structure? Journal of Economics, 18, 157-177.

Braukmann, U., Bijedic, T., \& Schade, C. (2008). Unternehmerische persönlichkeit - Eine theoretische rekonstruktion und normaldefinitorische konturierung. Wuppertal: Schumpeter School of Business and Economics.

Brown, J. T., \& Kant, A. C. (2008). Creating bioentrepreneurs: How graduate student organisations foster science entrepreneurship. Journal of Commercial Biotechnology, 15(2), 125-35.

Büyüköztürk, Ş. (2006). Veri analizi el kitabı [Data analysis handbook]. Ankara: Pegem A Yayıncılık.

Caliendo, M., \& Kritikos, A. S. (2011). Searching for the entrepreneurial personality: New evidence and avenues for further research. IZA Discussion Papers 5790, Institute of Labor Economics (IZA).

Cardy L., \& Selvarajan, R. (2006). Competencies: Alternative frameworks for competitive advantage. Business Horizons, 49(3), 235-245.

Chrisman, J. J., Hynes, T., \& Fraser, S. (1995). Faculty entrepreneurship and economic development: The case of the University of Calgary. Journal of Business Venturing, 10(4), 267-281.

Clark, B. R. (1998). Creating entrepreneurial university: Organizational pathways of transformation. UK: Emerald Group Publishing Limited.

Collins, C. J., Hanges, P. J., \& Locke, E. A. (2004). Therelationship of achievement motivation to entrepreneurial behavior: A metaanalysis. Human performance, 17(1), 95-117.

Çavuş, M. F., \& Pekkan, N. Ü. (2017). Algılanan sosyal desteğin sosyal girişimciliğe etkisi: Üniversite öğrencileri üzerinde bir araştrrma [The effect of perceived social support on social entrepreneurship: A study on university students]. Business and Economics Research Journal, 8(3), 519-532.

Çetin, F., \& Varoğlu, A. K. (2009). Özellikler bağlamında girişimcinin beş faktör kişilik örüntüsü [The entrepreneur's five factor personality pattern in terms of characteristics]. Savunma Bilimleri Dergisi, 8(2), 51-66.

Çokluk, O., Şekercioğlu, G., \& Büyüköztürk, Ş. (2012). Sosyal bilimler için çok değişkenli SPSS ve LISREL uygulamaları [Multivariate SPSS and LISREL applications for social sciences]. Ankara: Pegem Akademi Yayıncılık.

Dill, D. D. (2003). Allowing the market to rule: The case of the United States. Higher Education Quarterly, 57(2), 136-157.

Donckels, R. (1991). Education and entrepreneurship experiences from secondary and university education in Belgium. Journal of small business \& entrepreneurship, 9(1), 35-42.

Etzkowitz H. (2004). The evolution of the entrepreneurial university. International Journal of Technology and Globalisation, 1(1), 64-77.

Etzkowitz, H. (1983). Entrepreneurial scientists and entrepreneurial universities in American academic science. Minerva, 21, 1-21.

Fernie, D. E., Kantor, R., Klein, E. L., Meyer, C., \& Elgas, P. M. (1988). Becoming students and becoming ethnographers in a preschool. Journal of Research in Childhood Education, 3(2), 132-141. 
Field, A. (2009). Discovering statistics using SPSS (3rd Edition), London: Sage Publications Ltd.

Galloway, L., \& Brown, W. (2002). Entrepreneurship education at university: A driver in the creation of high growth firms? Education+ Training, 44(8-9), 398-405.

Goldberg, L. R. (1992). The development of markers for the BigFive factor structure. Psychological Assessment, 4(1), 26-42.

Jacob, M., Lundqvist, M., \& Hellsmark, H. (2003). Entrepreneurial transformations in the Swedish university system: the case of Chalmers University of Technology. Research Policy, 32, 15551568.

Jacobsen, L. (2003). Bestimmungsfaktoren für erfolg im entrepreneurship. Unpublished doctoral dissertation, FB Erziehungswissenschaft, Freie Universität zu Berlin, Germany.

Johannisson, B. (1991). University training for entrepreneurship: Swedish approaches. Entrepreneurship \& Regional Development, 3(1), 67-82.

John O. P., \& Srivastava, S. (1999). The Big Five trait taxonomy: History, measurement, and theoretical perspectives. In: L. A. Pervin, \& O. P. John (Eds.), Hand-book of Personality: Theory and research (pp. 102-138). New York: The Guilford Press.

Johns, G. (2006). The essential impact of context on organizational behavior. Academy of Management Review, 31(2), 386-408.

Kailer, N. (2005). Komzeptualisierung der entrepreneurship education an hochschlen: Empirische ergebnisse, problemfelder und gestantlungsansätze. Zeitschrift für KMU und Entrepreneurship, 53(3), 165-184.

Kailer, N., \& Weiß, G. (2018). Gründungsmanagement kompakt: Von der idee zum businessplan. Wien: Linde Verlag.

Karabulut, T. (2009). Üniversite öğrencilerinin girişimcilik özelliklerini ve eğilimlerini belirlemeye yönelik bir araştırma [A research to determine the entrepreneurial characteristics and tendencies of university students], Marmara Üniversitesi iiBF Dergisi, 16(1), 331-356.

Kerr, S. P., Kerr, W. R., \& Xu, T. (2018). Personality traits of entrepreneurs: A review of recent literature. Foundations and Trends ${ }^{\circledR}$ in Entrepreneurship, 14(3), 279-356.

Khanal A. B. (2016). Sampling. In: A. B. Khanal (Ed.), Mahajan's methods in biostatistics for medical students and research workers (pp. 113-127). $8^{\text {th }}$ ed. New Delhi, India: Jaypee Brothers Medical Publishers (P).

Kiggundu, M. N. (2002). Entrepreneurs and entrepreneurship in Africa: What is known and what needs to be done. Journal of Developmental Entrepreneurship, 7(3), 239-258.

Kocabacak, A. (2011). Insan kaynaklari seçme ve yerleştirme süreci açisindan kişilik boyutları ile çalışan performansı ilişkisi: ilaç sektöründe psikoteknik boyutta bir uygulama [Relationship between personality dimensions and employee performance in terms of human resources selection and placement process: A psychotechnical application in the pharmaceutical industry]. Doktora tezi, Selçuk Üniversitesi, Konya.

Korunka, C., Frank, H., Lueger, M., \& Mugler, J. (2003). The entrepreneurial personality in the context of resources, environment, and the startup process - A configurational approach. Entrepreneurship theory and practice, 28(1), 23-42.
Korunka, C., Kessler, A. , Frank, H., \& Lueger, M. (2011). Personal characteristics, resources, and environment as predictors of business survival. Journal of Occupational and Organizational Psychology, 83, 1025-1051.

Koyuncuoğlu, Ö., \& Tekin, M. (2019). Türkiye'de girişimci ve yenilikçi üniversitelerin gömülü teoriye göre değerlendirmesi ve bir model önerisi [Evaluation and recommendation of a model based on the theory embedded in the entrepreneurial and innovative universities in Turkey]. Selçuk Üniversitesi Sosyal Bilimler Enstitü Dergisi, 41, 16-31.

Markowska, M. (2011). Entrepreneurial competence development: Triggers, processes and consequences. JIBS Dissertation Series No. 071, Jönköping International Business School, Printed by ARK Tryckaren.

Mc Adams, D. P. (1997). A conceptual history of personality psychology. Academic Press.

McNally, J. J., Martin, B. C., Honig, B., Bergmann, H., \& Piperopoulos, P. (2016). Toward rigor and parsimony: A primary validation of kolvereid's (1996) entrepreneurial attitudes scales. Entrepreneurship \& Regional Development, 28(5-6), 358-379.

Minniti, M., Bygrave, W. D., \& Autio, E. (2006). Global entrepreneurship monitör: Executive Report 2005, London.

Morris, M. H., Shirokova, G., \& Tsukanova, T. (2017). Student entrepreneurship and the university ecosystem: A multicountry empirical exploration. European Journal International Management, 11(1), 65-85.

Mould, C. (2013). Do personality traits predict entrepreneurial intention and performance? Unpublished master's thesis, Faculty of Commerce, University of Cape Town.

Muofhe, N. J., \& Du Toit, W. F. (2011). Entrepreneurial education's and entrepreneurial role models' influence on career choice. SA Journal of Human Resource Management, 5(1), 243-257.

Murugesan, R., \& Jayavelu, R. (2017). The influence of big five personality traits and self-efficacy on entrepreneurial intention: the role of gender. Journal Of Entrepreneurship and Innovation in Emerging Economies, 3(1), 41-61.

Müller, G. F. (2005). F-DUP. Fragebogen zur diagnose unternehmerischer potentiale. In: W. Sarges, \& H. Wottawa (Eds.), Handbuch wirtschaftspsychologischer testverfahren (pp. 337341). Lengerich: Pabst.

Norman, W. T. (1963). Toward an adequate taxonomy of personality attributes: Replicated factor structure in peer nomination personality ratings. Journal of Abnormal and Social Psychology, 66, 574-583.

Odabaşı, Y. (2007). 21.yüzyil'in üniversite modeli olarak girişimci üniversiteler [Entrepreneurial universities as the university model of the 21st century]. In: C. C. Aktan (Ed.), Değişim Çağında Yükseköğretim Global Trendler-Paradigmal Yönelimler [Higher education global trends - Paradigmal trends in the age of change] (pp. 117-133). İzmir: Yaşar Üniversitesi Yayını.

Özutku H., \& Algur, O. (2012). Uluslararası görevler için yönetici seçiminde ve performans değerlemesinde yetkinliklerin kullanimi: Perfetti Van Melle Gıda San. Tic. A.Ş. Örneği [Use of competencies in executive selection and performance appraisal for international duties: Perfetti Van Melle Gıda San. Tic. A.S. Example]. Süleyman Demirel Üniversitesi Iktisadi ve idari Bilimler Fakültesi Dergisi, 17(3), 53-73. 
Pattr, S., \& Karahan, M. (2010). Girişimcilik eğitimi ve üniversite öğrencilerinin girişimcilik profillerinin belirlenmesine yönelik bir alan araştırması [A field study on entrepreneurship education and determining the entrepreneurship profiles of university students]. Işletme ve Ekonomik Araşttrmalar Dergisi, 1(2), 27-44.

Pott, O., \& Pott, A. (2012). Entrepreneurship, unternehmensgründung, unternehmerisches handeln und rechtliche aspekte. Heidelberg: Springer.

Raab, G., \& Neuner, M. (2008). Gründungsrelevante persönlichkeitsmerkmale von wirtschaftsstudenten in Deutschland und den USA: Eine vergleichende empirische untersuchung. In: S. Kraus, \& K. Gundolf (Eds.), Stand und perspektiven der deutschsprachigen entreneurship- und KMU-Forschung (pp. 305-321). Köln: ibidem.

Rathgens, F. (2012). Eine reflexion der persönlichkeit im kontext des gründungsprozesses. In: W. Fröhlich (Ed.), Unternehmensgründung und Persönlichkeit (pp. 21-42). Mering: Rainer Hampp Verlag.

Rauch, A., \& Frese, M. (2007). Tet's put the person back into entrepreneurship research: A meta-analysis on the relationship between business owners' personality traits, Business Creation, and Success. European Journal of Work and Organizational Psychology, 16, 353-385.

Robertson, I. (2008). Comment: How universities and graduates can thrive. Retrieved from http://www.independent. co.uk/student/career-planning/getting-job/comment-howuniversities-and-graduates-can-thrive-918572.html.

Saßmannshausen, W. (2008). Waldorf-Pädagogik auf einen blick: Einführung für den kindergarten. Herder Freiburg.

Schick, H. (2007). Unternehmensgründung und nachhaltigkeit, schriften zur nachhaltigen unternehmensentwicklung. München/Metering: Rainer Hampp.

Schmitt-Rodermund, E. (2004). Pathways to successentrepreneurial competence, and interests. Journal of Vocational Behavior, 65, 498-518.

Schumpeter, J. A., Becker, M. C., Knudsen, T., \& Swedberg, R. (2011). The entrepreneur: classic texts by Joseph A. Schumpeter. Stanford, Calif., Stanford University Press.

Setiawan, J. L. (2014). Examining entrepreneurial self-efficacy among students. Procedia - Social and Behavioral Sciences, 115, 235-242.

Sharma, L., \& Madan, P. (2013). Affect of perceived barriers to entrepreneurship on the career choice decision of students: A study of Uttarkhand state, India. Business and Economic Horizons, 9, 23-33.

Singh, G., \& DeNoble, A. (2003). Early retirees as the next generation of entrepreneurs. Entrepreneurship Theory and Practice, 27(3), 207-226.
Subotzky, G. (1999). Beyond the entrepreneurial university: The potential role of South Africa's historically disadvantaged institutions. In Reconstruction and Development International Review of Education, 45(6), 507-527.

Tabachnick, B. G., \& Fidell, L. S. (2007). Using multivariate statistics. Boston: Allyn and Bacon.

Tavşancıl, E. (2005). Tutumların ölçülmesi ve SPSS ile veri analizi [Measuring attitudes and data analysis with SPSS.]. Ankara: Nobel Yayın Dağıtım.

Tekin, M., Baş, D., Geçkil, T., \& Koyuncuoğlu, Ö. (2019). Entrepreneurial competences of university students in the digital age: A scale development study. In: N. M. Durakbasa, \& M. G. Gençyılmaz (Eds.), Proceedings of the International Symposium for Produktion Research 2019 (pp. 593-604). Cham: Springer Nature Schwitzerland AG 2020.

Tekin, M., Koyuncuoğlu, Ö., Geçkil, T., \& Baş, D. (2019). Evaluation of entrepreneurial-innovative university conditions and activities from students' point of view in the context of industry 4.0. In: N. M. Durakbasa, \& M. G. Gençyılmaz (Eds.), Proceedings of the International Symposium for Produktion Research 2019 (pp. 605-618). Cham: Springer Nature Schwitzerland AG 2020.

Thomson, G. S., \& Minhas, W. (2017). Enabling entrepreneurship: entrepreneurial intentions among emirati students. Journal of Enterprising Culture, 25(2), 211-237.

Top, S., \& Öner, A. (2012). İşletme perspektifinden sosyal sorumluluk teorisinin incelenmesi [Study of social responsibility theory from a business perspective]. Uluslararası Yönetim iktisat ve işletme Dergisi, 4(7), 95-108.

Turan, N. (2015). Çalışma yaşamında yetenek, beceri, yetkinlik, yeterlilik [Talent, skill, competence, competence in working life]. Nobel Akademik Yayıncılık, Ankara.

Vatansever, Ç. (2011). Türkiye'de bir yetkinlik olarak girişimcilik [Entrepreneurship as a competence in Turkey]. Balkan Journal of Social Sciences, 2(1), 1-9.

Wissema, J. G. (2014). Üçüncü kuşak üniversitelere doğru [Towards third generation university]. İstanbul, Özyeğin Üniversitesi Yayıncılık.

Yazıcıoğlu, Y., \& Erdoğan, S. (2014). SPSS uygulamali bilimsel araştirma yöntemleri [SPSS applied scientific research methods]. Ankara: Detay Yayıncılık.

Yıldırım, E. (2015). İstatistiksel araştirma yöntemleri [Statistical research methods], Ankara: Seçkin Yayıncılık.

Zhao, H., \& Seibert, S. E. (2006). The Big Five personality dimensions and entrepreneurial status: A meta-analytical review. Journal of Applied Psychology, 91, 259-271.

Zhao, H., Seibert, S. E., \& Lumpkin, G. T. (2010). The relationship of personality to entrepreneurial intentions and performance: A meta-analytic review. Journal of Management, 36(2), 381404. 